\title{
The Effect of Work Discipline and Job Performance on Job Promotion at PT. Daya Sakti Perkasa In Tangerang
}

\author{
Zacharia Rialmi $^{1}$, Lia Asmalah ${ }^{2}$ \\ 1.2 Universitas Pamulang \\ E-mail: dosen01566@unpam.ac.id
}

(Received: December-2017; Reviewed: January-2018; Accepted: February-2018;

Avalaibel Online: February-2018; Published: March-2018)

(7) (8) This is an open access article distributed under the Creative Commons Attribution License

EY NC CC-BY-NC-4.0 @2018 by author (https://creativecommons.org/licenses/by-nc/4.0/)

\begin{abstract}
Leaders must realize the importance of promotion in increasing productivity which must be considered objectively. The purpose of this study was to determine the effect of work discipline and work performance on job promotions at PT. Daya Sakti Perkasa in Tangerang. The method used in this research is descriptive with an associative approach, the sampling technique used is proportional random sampling using the census or saturated sampling method with a sample of 78 respondents. The analysis tool uses instrument testing, classical assumption testing, regression testing, determination coefficient testing and hypothesis testing. The results of the study concluded that there was a positive and significant effect both partially and simultaneously between work discipline and work performance on promotion with a contribution of 0.576 or $57.6 \%$ while the remaining $42.4 \%$ was influenced by other factors. Hypothesis testing is obtained F count $>\mathrm{F}$ table $(50.850>2.730)$ thus $\mathrm{H} 0$ is rejected and $\mathrm{H} 3$ is accepted meaning that there is a positive and significant effect simultaneously between work discipline and work performance on job promotions at PT. Daya Sakti Perkasa in Tangerang.
\end{abstract}

Keywords: Work discipline; work performance; promotion

\section{INTRODUCTION}

Human resource is an asset of the organization that is very valuable and as the main role that is as a regulator of other resources (Akhmad, 2016; Awaliah, Amirullah, \& Saleh, 2015; Erawati, Darwis, \& Nasrullah, 2017). The management of an organization is very much determined by the activities of empowering human resources. Where human resource is an organizational asset that is very valuable and as the main role that is as a regulator of other resources. Every activity carried out in an organization will not be separated from human resources (Amirullah \& Saleh, 2015; Rosmani, Amirullah, \& Saleh, 2015). Because no matter how sophisticated the technology, humans are still a very important factor.

Organization as an embodiment of the interaction between humans that produce cooperation that never stops as long as humans are gathered therein. In other words, the 
collaboration carried out within the organization is ongoing (Sobirin, 2014; Suwatno, 2011; Winardi, 2006). Organization as a form of alliance between two or more people who work together formally in order to achieve certain goals (Kumorotomo \& Margono, 2001; Oemar, 2013; Robbins, 2001; Winardi, 2006)

Work discipline can be seen as something of great benefit, both for the interests of the company and for employees, for the company the existence of work discipline will guarantee the maintenance of order and the smooth implementation of tasks so that optimal results are obtained (Sunarsi, 2016, Sunarsi 2017). As for employees, a pleasant working atmosphere will be obtained so that it will increase morale in carrying out their work. Thus, employees can carry out their duties with full awareness and can develop energy and mind to the fullest.

Line managers and company leaders need to pay attention to employees in order to achieve a better position. Therefore, companies need to hold promotions to provide opportunities for employees to improve their position in the company (Iskandar \& Pasaribu, 2015; Rahayu, 2017; Saputra, Dicky, Nurlina, 2017). To be able to carry out employee promotions appropriately, it is necessary to have an assessment of work performance that will describe the work performance of employees within a certain period of time. Through this assessment, it can be seen the weaknesses and strengths of the employees in carrying out their work, as well as the extent of expertise and ability in work (Anto, Mustafidah, \& Suyadi, 2015; Maulana, 2012; Siti Noni Evita, Wa Ode Zusnita Muizu, 2017; Yoga Handoko Agustin \& Kurniawan, 2015). An assessment of work performance will enable the establishment of promotion policies based on objective considerations. Performance appraisal must also be done honestly, fairly and objectively as possible without nepotism and to avoid jealousy among employees (Anita, Aziz, \& Yunus, 2013; Leong \& Rasli, 2014; Malek shah Mohd Yusoff \& Nor Shah Mohamed, 2004). This is important to maintain harmony in the corporate environment. This assessment can be used as a basis for determining the right criteria for carrying out promotions. The company can determine who is entitled to carry out the promotion based on the results of the work performance assessment.

Every organization expects that its employees can perform well. From the results of employee performance evaluations, it can be seen whether an employee can work well or not as seen from the assessment categories compared between benchmarks of organizational performance appraisal with employee performance so that it can be interpreted that the higher assessment is an indication that the employee's performance is able to meet performance expectations organization (Adha, Qomariah, \& Hafidzi, 2019; Taurisa \& Ratnawati, 2012; Trihandini, 2005).

The work performance appraisal program has been carried out by PT. Daya Sakti Perkasa routinely twice a year. But in reality, the assessment of work performance is not yet optimal. This is due to the lack of objective judgment and the presence of elements of favoritism and nepotism. Employees' work performance is in the medium criteria, this can be seen in the value of the work targets in general, only in the category of good, moderate and sufficient, has not reached very good levels. If employees have the motivation for the opportunity to be promoted in their work, then they generally have high discipline and motivation. Conversely, if their morale or morale is low, then they can adjust to bad habits. They might even not be polite to the leader.

With the promotion target, surely employees will feel valued, cared for, needed and recognized by their company management capabilities so that they will produce high outputs and will enhance loyalty or loyalty to the company (Assauri, 2008; Sudana, 2011). Therefore, 
leaders must realize the importance of promotion in increasing productivity which must be considered objectively. If the leadership has realized and considered, then the company will avoid problems that hinder increased output and can be detrimental to the company such as employee dissatisfaction, income complaints, lack of morale, decreased work discipline, high absenteeism or even problems work strike.

\section{METHOD}

The type of data used is quantitative with primary data sources by distributing questionnaires which are then tabulated and feasibility analysis and secondary data derived from the various scientific literature. The population in this study were employees of PT. Daya Sakti Perkasa in Tangerang. Sampling was used saturation sampling technique that is 78 employees. The instrument testing uses validity and reliability tests. From the validity and reliability test stated valid and reliable, this is evidenced by the value of $r$ count $>r$ table, likewise, the instrument used is appropriate and feasible to be forwarded to the next test. Testing for normality using Kolmogorov Smirnov obtained significance greater than 0.50 and thus declared normal. Multicollinearity testing obtained tolerance values $<1$ and VIF $<10$ so that it was concluded there was no interference with multicollinearity. Autocorrelation testing obtained the value of Durbin-Watson at an interval of 1.550 - 2.460, thus this regression model does not have autocorrelation. Heteroskesdastisitas testing with Glejser test obtained significance values greater than 0.05 so it was concluded that there was no interference with heteroscedasticity.

\section{RESULT AND DISCUSSION}

PT. Daya Sakti Perkasa in Tangerang, a company engaged in manufacturing machinery, tools, molding, steel fabrication, and steel casting, will support the creation of high-performance company employees. Thus a strong company will be created, and able to compete in the midst of the rapid progress of the times. PT. Daya Sakti Perkasa in Tangerang is also a fast-growing company, as evidenced by the construction of a new factory in the Tigaraksa Millennium industrial area in Tangerang and the opening of a new factory in the Tunas industrial area of Batam Island. This shows that PT. Daya Sakti Perkasa in Tangerang can still exist in the midst of competition with similar companies that exist today.

\section{Descriptif Analysis}

The criteria of the object under study are based on respondents' responses to the statement items obtained as follows:

Table 1.

The Result of Multiple Regression Processing Variables in Work Discipline (X1) and Job Performance (X3) on Job Promotion (Y)

\begin{tabular}{|lr|r|r|r|r} 
& N & Minimum & Maximum & \multicolumn{1}{c}{ Mean } & \multicolumn{1}{c}{ Std. Deviation } \\
\hline Work Discipline (X1) & 78 & 32.00 & 48.00 & 38.3077 & 4.04619 \\
\hline Work Performance (X2) & 78 & 30.00 & 46.00 & 38.1410 & 3.80609 \\
\hline Job Promotion (Y) & 78 & 32.00 & 47.00 & 38.8846 & 3.70672 \\
\hline
\end{tabular}




Valid N (listwise) $\quad 78$

Work discipline variable (X1) obtained an average score of 3.83 with a standard deviation of 40.5, work performance variable (X2) of 3.81 with a standard deviation of 38.0 and a promotion variable (Y) of 3.89 with a standard deviation 37.1, all three variables obtained all scores were in the scale range of 3.40 - 4.19 with good criteria.

Work discipline is very important to be owned by employees or employees in an organization to support optimal organizational goals. Job performance is the level of ability possessed by employees in carrying out their duties and obligations. Job promotion is a form of appreciation of a company or organization for its employees who have certain abilities and work achievements to be given the opportunity to go up to the top level or to work better.

\section{Analisis Kuantitatif}

Quantitative analysis is intended to determine the magnitude of influence and analyze the significance of these influences.

The regression test is intended to find out how much influence the dependent variable has on the dependent variable. The following results of the processed regression data can be seen in the following Table 2:

Table 2

The Result of Multiple Regression Processing Variables in Work Discipline (X1) and Job Performance (X3) on Job Promotion (Y)

\begin{tabular}{|c|c|c|c|c|c|c|}
\hline \multirow{3}{*}{\multicolumn{2}{|c|}{ Model }} & \multicolumn{3}{|c|}{ Coefficients $^{\mathrm{a}}$} & \multirow[b]{3}{*}{$\mathrm{t}$} & \multirow[b]{3}{*}{ Sig. } \\
\hline & & \multicolumn{2}{|c|}{$\begin{array}{l}\text { Unstandardized } \\
\text { Coefficients }\end{array}$} & \multirow{2}{*}{$\begin{array}{c}\text { Standardized } \\
\text { Coefficients } \\
\text { Beta } \\
\end{array}$} & & \\
\hline & & $\mathrm{B}$ & Std. Error & & & \\
\hline 1 & (Constant) & 8.825 & 2.994 & & 2.948 & .004 \\
\hline & Work Discipline (X1) & .338 & .093 & .369 & 3.650 & .000 \\
\hline & Work Performance (X2) & .448 & .099 & .460 & 4.553 & .000 \\
\hline
\end{tabular}

a. Dependent Variable: Job Promotion (Y)

Based on the analysis of the regression calculations in Table 2, the regression equation $\mathrm{Y}=8.825+0.338 \mathrm{X} 1+0.448 \mathrm{X} 2$ can be obtained. A constant value of 8.825 means that if the work discipline variable (X1) and work performance (X2) are absent then there is a promotion value (Y) of 8.825 points. X1 value of 0.338 is interpreted if the constant is constant and there is no change in the work performance variable (X2), then every 1 unit change in the work discipline variable (X1) will result in a change in the promotion (Y) of 0.338 points. $\mathrm{X} 2$ value of 0.448 is interpreted if the constant is constant and there is no change in the work discipline variable (X1), then every 1 unit change in the work performance variable (X2) will result in a change in the promotion (Y) of 0.448 points.

Analysis of the coefficient of determination is intended to determine the percentage strength of the relationship between the independent variables on the dependent variable both partially and simultaneously), in this study the variable work discipline (X1) and 
work performance $(\mathrm{X} 2)$ on the promotion of position $(\mathrm{Y})$. Here are the results of the calculation of the coefficient of determination whose test results are as follows:

Table 3

Results of Partial Determination Coefficient Analysis Between Work Discipline (X1) Against Job Promotion (Y)

\begin{tabular}{lr|r|r|r} 
& \multicolumn{4}{c}{ Model Summary } \\
Model & $\mathrm{R}$ & R Square & Adjusted R Square & $\begin{array}{c}\text { Std. Error of the } \\
\text { Estimate }\end{array}$ \\
\hline 1 & $.677^{\mathrm{a}}$ & .458 & .451 & 2.74617 \\
\hline
\end{tabular}

a. Predictors: (Constant), Work Discipline (X1)

Based on the test results in Table 3, the R-square value (determination coefficient) of 0.458 can be concluded that the work discipline variable (X1) influences the promotion variable $(\mathrm{Y})$ of $45.8 \%$ while the remaining $54.2 \%$ is influenced by other factors.

Table 4

Results of Partial Determination Coefficient Analysis Between Job Performance (X2) Against Job Promotion (Y)

\begin{tabular}{|c|c|c|c|c|}
\hline \multirow[b]{2}{*}{ Model } & \multicolumn{3}{|c|}{ Model Summary } & \multirow[b]{2}{*}{$\begin{array}{l}\text { Std. Error of the } \\
\text { Estimate }\end{array}$} \\
\hline & $\mathrm{R}$ & R Square & Adjusted R Square & \\
\hline 1 & $.707^{\mathrm{a}}$ & .500 & .494 & 2.63782 \\
\hline
\end{tabular}

Based on the test results in Table 4, the R-square value of 0.500 is obtained, it can be concluded that the work performance variable (X2) influences the promotion variable (Y) by $50.0 \%$ while the remaining $50.0 \%$ is influenced by other factors.

Table 5

Results of Simultaneous Determination Coefficient Analysis of Work Discipline (X1) and Job Performance (X2) Toward Job Promotion (Y)

\begin{tabular}{l|r|rr|r}
\multicolumn{5}{c}{ Model Summary } \\
Model & \multicolumn{2}{c}{} & \\
\hline 1 & R Square & Adjusted R Square & Std. Error of the Estimate \\
\hline a. Predictors: (Constant), Work Performance (X2), Work Discipline (X1) & .564 & 2.44690 \\
\hline
\end{tabular}


Based on the test results in Table 5, the R-square value of 0.576 is obtained so it can be concluded that the work discipline variable (X1) and work performance (X2) influence the promotion variable (Y) of 54.6\% while the remaining $42.4 \%$ is influenced by other factors that were not carried out by the study.

Hypothesis testing of work discipline variables (X1) and work performance (X2) on job promotion $(\mathrm{Y})$ is done by $\mathrm{t}$-test (partial test). In this study the significance criteria used $5 \%(0.05)$ with the following results:

Table 6

Hypothesis Test Results (t-Test) Work Discipline Variable (X1) Toward Job Promotion (Y)

\section{Coefficients $^{\mathrm{a}}$}

\begin{tabular}{|c|c|c|c|c|c|c|}
\hline \multirow{2}{*}{\multicolumn{2}{|c|}{ Model }} & \multicolumn{2}{|c|}{$\begin{array}{l}\text { Unstandardized } \\
\text { Coefficients }\end{array}$} & \multirow{2}{*}{$\begin{array}{c}\text { Standardized } \\
\text { Coefficients } \\
\text { Beta }\end{array}$} & \multirow[b]{2}{*}{$\mathrm{t}$} & \multirow[b]{2}{*}{ Sig. } \\
\hline & & $\mathrm{B}$ & Std. Error & & & \\
\hline \multirow[t]{2}{*}{1} & (Constant) & 15.128 & 2.979 & & 5.078 & .000 \\
\hline & Work Discipline(X1) & .620 & .077 & .677 & 8.018 & .000 \\
\hline
\end{tabular}

a. Dependent Variable: Job Promotion (Y)

Based on the test results in Table 6 , the value of $t_{\text {count }}>t_{\text {table }}$ or $(8.018>1.992)$ is also strengthened by the value of $\rho$ value $<$ Sig. 0.05 or $(0,000<0.05)$. Thus, H0 is rejected and $\mathrm{H} 1$ is accepted, this shows that there is a positive and partially significant effect between work performance on job promotions at PT. Daya Sakti Perkasa in Tangerang.

Table 7

Hypothesis Test Results (t Test) Job Performance (X2) Against Job Promotion (Y)

Coefficients $^{\mathrm{a}}$

\begin{tabular}{|c|c|c|c|c|c|c|}
\hline \multirow{3}{*}{\multicolumn{2}{|c|}{ Model }} & \multicolumn{2}{|c|}{ Coefficlents $^{a}$} & \multirow{2}{*}{$\begin{array}{l}\text { Standardized } \\
\text { Coefficients }\end{array}$} & \multirow[b]{3}{*}{$\mathrm{t}$} & \multirow[b]{3}{*}{ Sig. } \\
\hline & & \multicolumn{2}{|c|}{$\begin{array}{l}\text { Unstandardized } \\
\text { Coefficients }\end{array}$} & & & \\
\hline & & B & Std. Error & Beta & & \\
\hline 1 & (Constant) & 12.615 & 3.027 & & 4.167 & .000 \\
\hline & Work Performance (X2) & 689 & .079 & .707 & 8.721 & .000 \\
\hline
\end{tabular}

a. Dependent Variable: Promosi Jabatan (Y)

Based on the test results in Table 7 obtained the value of $t_{\text {count }}>t_{\text {table }}$ or $(8,721>$ 1,992). This was also reinforced by the value of $\rho$ value $<$ Sig. 0.05 or $(0,000<0.05)$. Thus, $\mathrm{H} 0$ is rejected and $\mathrm{H} 2$ is accepted, this shows that there is a positive and partially 
significant effect between work performance on job promotions at PT. Daya Sakti Perkasa in Tangerang.

For testing the effect of variable work performance and work performance simultaneously on the promotion of position at PT. Daya Sakti Perkasa in Tangerang was carried out with a statistical $F$ test (simultaneous test) with a significance of $5 \%$. In this study, the significance criteria used 5\% (0.05). The test results are as follows:

Table 8

Hypothesis Results (Test F) Simultaneously Work Discipline (X1) and Job Performance (X2) Toward Job Promotion (Y)

\begin{tabular}{|c|c|c|c|c|c|c|}
\hline \multicolumn{7}{|c|}{ ANOVA $^{a}$} \\
\hline \multicolumn{2}{|c|}{ Model } & Sum of Squares & $\mathrm{df}$ & Mean Square & $\mathrm{F}$ & Sig. \\
\hline 1 & Regression & 608.911 & 2 & 304.455 & 50.850 & $.000^{\mathrm{b}}$ \\
\hline & Residual & 449.051 & 75 & 5.987 & & \\
\hline & Total & 1057.962 & 77 & & & \\
\hline
\end{tabular}

a. Dependent Variable: Job Promotion (Y)

b. Predictors: (Constant), Work Performance(X2), Work Discipline (X1)

Based on the test results in Table 8 , the calculated $\mathrm{F}$ value $>\mathrm{F}$ table or $(50.850>$ $2.730)$ is also strengthened by the $\rho$ value $<$ Sig. 0.05 or $(0,000<0.05)$. Thus, H0 is rejected and $\mathrm{H} 3$ is accepted, this shows that there is a positive and significant simultaneous influence between work performance and work performance on job promotions at PT. Daya Sakti Perkasa in Tangerang.

\section{CONCLUSION}

Based on the results of the study, it was found that work discipline (X1) had a positive and significant effect on job promotion $(\mathrm{Y})$ with a coefficient of determination of $45.8 \%$. Job performance (X2) has a positive and significant effect on job promotions (Y) with a coefficient of determination of $50.0 \%$. Work discipline (X1) and work performance (X2) have positive and significant effect on job promotion $(\mathrm{Y})$ with a regression equation $\mathrm{Y}=8.825+0.338 \mathrm{X} 1+$ $0.448 X 2$. The coefficient of determination or effect simultaneously was $57.6 \%$ while the remaining $42.4 \%$ was influenced by other factors. Hypothesis testing obtained the value of $\mathrm{F}$ count $>\mathrm{F}$ table or $(50.850>2.730)$, this is also strengthened with a significant probability of $0,000<0.05$. Thus $\mathrm{H} 0$ is rejected and $\mathrm{H} 3$ is accepted. This means that there is a positive and significant effect simultaneously between work performance and work performance on job promotions at PT. Daya Sakti Perkasa in Tangerang.

\section{REFERENCES}

Adha, R. N., Qomariah, N., \& Hafidzi, A. H. (2019). Pengaruh Motivasi Kerja, Lingkungan Kerja, Budaya Kerja Terhadap Kinerja Karyawan Dinas Sosial Kabupaten Jember. Jurnal Penelitian IPTEKS. https://doi.org/10.32528/ipteks.v4i1.2109

Akhmad, A. (2016). Pengaruh Profesionalisme Sumber Daya Manusia terhadap Kinerja Pelayanan di Kantor Samsat Pinrang. Jurnal Office, 2(2), 103-108. 
Amirullah, A. H., \& Saleh, S. (2015). Pengaruh Budaya Organisasi terhadap Kinerja Pegawai Pada Kantor Lembaga Penjaminan Mutu Pendidikan (LPMP) Provinsi Sulawesi Selatan di Kota Makassar. Jurnal Office, 1(1), 24-31.

Anita, J., Aziz, N., \& Yunus, M. (2013). Pengaruh Penempatan Dan Beban Kerja Terhadap Motivasi Kerja Dan Dampaknya Pada Prestasi Kerja Pegawai Dinas Tenaga Kerja Dan Mobilitas Penduduk Aceh. Pascasarjana Universitas Syiah Kuala.

Anto, A. G., Mustafidah, H., \& Suyadi, A. (2015). Sistem Pendukung Keputusan Penilaian Kinerja Karyawan Menggunakan Metode SAW ( Simple Additive Weighting ). Juita.

Assauri, S. (2008). Manajemen Produksi dan Operasi. Jakarta: Lembaga Penerbit Fakultas Ekonomi Universitas Indonesia.

Awaliah, N., Amirullah, A. H., \& Saleh, S. (2015). Kinerja Pegawai Negeri Sipil pada Kantor Kementerian Agama Kota Makassar. Jurnal Office, 1(1), 13-17.

Erawati, I., Darwis, M., \& Nasrullah, M. (2017). Efektivitas Kinerja Pegawai pada Kantor Kecamatan Pallangga Kabupaten Gowa. Jurnal Office, 3(1), 13-18.

Iskandar, \& Pasaribu, E. S. (2015). Sitem Pendukung Keputusan Promosi Jabatan Karyawan Dengan Metode Analytycal Hierarchy Process (AHP) Studi Kasus Pada PT.Selular Global Net Medan. Teknologi Dan Sistem Informasi.

Kumorotomo, W., \& Margono, S. A. (2001). Sistem Informasi Manajemen dalam Organisasiorganisasi Publik. Yogyakarta: Gadjah Mada University Press.

Leong, C. T., \& Rasli, A. (2014). The Relationship between Innovative Work Behavior on Work Role Performance: An Empirical Study. Procedia - Social and Behavioral Sciences. https://doi.org/10.1016/j.sbspro.2014.03.717

Malek shah Mohd Yusoff, \& Nor Shah Mohamed. (2004). Peningkatan Prestasi Di Tempat Kerja Melalui Aplikasi Kecerdasan Emosi. Jurnal Pengurusan Awam Jilid.

Maulana, M. R. (2012). Penilaian Kinerja Karyawan Di Ifun Jaya Textile Dengan Metode Fuzzy Simple Additive Weighted. Jurnal Ilmiah ICTech.

Oemar, Y. (2013). Pengaruh Budaya Organisasi, Kemampuan Kerja dan Komitmen Organisasi terhadap Organizational Citizenship Behavior (OCB) Pegawai pada BAPPEDA Kota Pekanbaru. Jurnal Aplikasi Manajemen. https://doi.org/1693-5241

Rahayu, S. (2017). Pengaruh Promosi Jabatan terhadap Kinerja Karyawan pada PT. Garuda Metalindo. Jurnal Kreatif.

Robbins, S. P. (2001). Perilaku Organisasi : Konsep, Kontroversi dan Aplikasi. In Prenhallindo. https://doi.org/10.1016/S0926-860X(03)00316-8

Rosmani, S. R., Amirullah, A. H., \& Saleh, S. (2015). Pengaruh Motivasi Kerja terhadap Kinerja Pegawai pada Dinas Kebersihan dan Pertamanan Kabupaten Soppeng. Jurnal Office, 1(1), 31-37.

Saputra, Dicky, Nurlina, dan L. H. (2017). Pengaruh Reward dan Punishment terhadap Produktivitas Kerja Karyawan PT. Kereta Api Indonesia Persero Divisi Regional II Sumatera Barat. Jurnal Manajemen dan Kewirausahaan.

Siti Noni Evita, Wa Ode Zusnita Muizu, R. T. W. A. (2017). Penilaian Kinerja Karyawan dengan Menggunakan Metode Behaviorally Anchor Rating Scale dan Management By 
Objectives. Pekbis Jurnal.

Sobirin, A. (2014). Organisasi dan Perilaku Organisasi. Budaya Organisasi, Pengertian, Makna dan Aplikasinya. https://doi.org/10.1080/09853111.2000.11105363

Sudana, I. M. (2011). Manajemen Keuangan Perusahaan Teori \& Praktik. In Erlangga. https://doi.org/10.1145/2505515.2507827

Sunarsi, D (2016). Pengaruh Minat, Motivasi Dan Kecerdasan Kognitif Terhadap Prestasi Belajar (Studi Kasus Pada Mahasiswa Program Studi S-1 Manajemen. Fakultas Ekonomi. Universitas Pamulang. Thn. Akademik 2015-2016). In Proceedings (Vol. 1, No. 1).

Sunarsi, D. (2017). Pengaruh Disiplin, Motivasi, Dan Kompetensi Terhadap Prestasi Belajar (Studi Kasus Pada Mahasiswa Universitas Pamulang, Tangerang Selatan Tahun Akademik 2016-2017). Jurnal Mandiri: Ilmu Pengetahuan, Seni, Dan Teknologi, 1(2), 207-226.

Suwatno, H. \& P. D. . (2011). Manajemen SDM Dalam Organisasi Publik \& Bisnis. In Manajemen.

Taurisa, C. M., \& Ratnawati, I. (2012). Analisis Pengaruh Budaya Organisasi dan Kepuasan Kerja terhadap Komitmen Organisasional dalam meningkatkan Kinerja Karyawan. Jurnal Bisnis dan Ekonomi (JBE). https://doi.org/ISSN: 1412-3126

Trihandini, R. A. F. M. (2005). Analisis Pengaruh Kecerdasan Intelektual, Kecerdasan Emosi dan Kecerdasan Spiritual terhadap Kinerja Karyawan (Studi Kasus di Hotel Horison Semarang).

Winardi, J. (2006). Teori Organisasi \& Pengorganisasian. Teori Organisasi \& Pengorganisasian.

Yoga Handoko Agustin, \& Kurniawan, H. (2015). Sistem Pendukung Keputusan Penilaian Kinerja Dosen Menggunakan Metode Weighted Product (Studi Kasus : Stmik Pontianak). Seminar Nasional Informatika 2015. 